\title{
VOCATIONAL AND SENIOR HIGH SCHOOL PROFESSIONAL TEACHERS IN INDUSTRY 4.0
}

\author{
Sunaryo Soenarto*, Sugito, Suyanta, Siswantoyo, Marwanti \\ Yogyakarta State University, Indonesia \\ *e-mail: sunaryos@uny.ac.id
}

\begin{abstract}
The teacher certification program has been implemented since 2007, yet the society has not optimally experienced the quality improvement of secondary education in Industry 4.0. This study aims to examine vocational and senior high school teacher professionalism in the age of Industry 4.0 in developing learning. This study employed the survey method with quantitative descriptive analysis. The sample of this study was taken from two provinces in Indonesia, namely Yogyakarta Special Region and West Borneo. The data were collected from 113 vocational and senior high school teachers using random purposive sampling. The instruments used in this research were open-ended and close-ended questionnaires. The results of this study show that there is still a low number of teachers with a Master's degree; however, teachers participate in various capacity building training programs. Moreover, the most common training programs for the teachers are on classroom action research, scientific journal publications, curriculum development, and updating teaching materials. Furthermore, it is found that the number of journal articles published by vocational and senior high school teachers in the two provinces is still low, and as a result, bottleneck problems may occur in their career promotion.
\end{abstract}

\section{Keywords: professionalism, teacher, industry 4.0}

\section{GURU PROFESIONAL DI SEKOLAH MENENGAH ATAS DAN SEKOLAH MENENGAH KEJURUAN DI ERA INDUSTRI 4.0}

\begin{abstract}
Abstrak: Program sertifikasi guru telah dilaksanakan sejak 2007, namun hingga saat ini peningkatan mutu pendidikan menengah di Indonesia belum optimal dirasakan masyarakat di era industri 4.0. Tujuan penelitian adalah untuk mendeskripsikan profesionalitas guru SMA dan SMK di era industri 4.0 dalam mengembangan pembelajaran. Penelitian ini menggunakan motode survei dengan analisis deskriptif kuantitatif. Sampel penelitian diambil dari dua provinsi di Indonesia, yaitu Daerah Istimewa Yogyakarta dan Kalimantan Barat. Data diperoleh secara purposif sampling dengan jumlah sampel guru SMA dan SMK sebanyak 113 orang. Instrumen yang digunakan dalam penelitian ini adalah kuesioner tertutup dan terbuka. Hasil penelitian ini menemukan bahwa peningkatan guru SMA dan SMK yang telah menempuh pascasarjana masih rendah, namun berbagai program pelatihan pengembangan diri telah diikuti. Penelitian juga menemukan, pelatihan yang dominan diikuti guru SMA dan SMK meliputi penelitian tindakan kelas, publikasi ilmiah, pengembangan kurikulum, dan pemutakhiran materi ajar. Temuan lain adalah bahwa guru SMA dan SMK di provinsi DIY dan Kalimantan Barat dalam publikasi ilmiah sangat rendah, yang diprediksi akan terjadi bootle neck dalam kenaikan pangkat.
\end{abstract}

Kata Kunci: profesionalitas, guru, era industri 4.0

\section{INTRODUCTION}

Indonesian Law RI 2003 No. 20 regarding the National Education System and Government Regulation No. 19 on National Education Standards (PP RI 2005 No. 19) define teachers as professional educators. Indonesian Ministry of Education and Culture explicitly states that professional teachers are required to have plenty of competencies. Competency is a series of knowledge, skills, and behaviors that teachers must possess and live with in order to carry out tasks in teaching. It is imperative for professional teachers to possesses pedagogical, professional, personality, and social competencies. In addition, Atay (2006) specifically mentions that pedagogical competency as well as recognizing and putting more attention to teacher 
professionalism play a big role in improving student achievement. The aforementioned competencies may be achieved by teachers through a series of training programs.

Education has a central role in preparing the generation to work in society, especially by mastering competencies according to the demands of the workforce in the industry 4.0. The main competency that must be possessed by the students is related to critical thinking, problem-solving, creativity, collaboration, and communication (Ananiadou \& Claro, 2009). They are the standard competencies that should be possessed by the students. Teacher's ability in conducting teaching-learning processes is one students'key to success for students in graduating from senior high schools since teachers play an important role in the educational system in schools.

Desimone, Smith, \& Ueno (2006) state that professional development is an important mechanism that can improve teachers' content knowledge and the quality of teaching practices. Thus, the Indonesian government through the Ministry of Education and Culture granted legal recognition to the teaching profession in 2005 . This is stated in the regulation of the Minister of Research, Technology and Higher Education (Permenristekdikti 2017 No. 55) concerning teacher education standards. Teachers are professional educators who have the main task of educating, teaching, guiding, directing, training, assessing, and evaluating students in the formal early childhood, elementary, and higher education.

Darling-Hammond (2000) argues that in managing an effective teaching-learning process, teachers must possess several competencies, including verbal communication skills, mastery of subject matter, having a graduate diploma, being certified teachers, and is experienced in teaching. Verbal communication skills are related to the teacher's ability to convey content knowledge orally and in writing, as well as in action to students in order to improve achievement. In terms of mastery of content knowledge, subject teachers are more likely to understand the teaching material extensively. The teachers should be able to master the subject matter to be able to transform it into instructions. Through Permenristekdikti 2017 No. 55 on teacher training standards, both competencies are considered as pedagogical and professional competencies (mastery of subject matter). These competencies should be improved in that professionalism is improved.

The implementation of quality education in Senior High Schools (SMA) and Vocational High Schools (SMK) must be able to deal with changes existing at the moment and in the future. The changes may be in the aspect of information technology and communication or science. Teacher as the agent of change in schools is responsible for coping with these changes. Craft (1996) stated that teachers face rapid changes, demand for high standards, and demands for quality improvement, thus requiring them to update and improve their knowledge and skills through learning.

Responding to the fourth industrial revolution era, teachers are expected to always improve competencies and professionalism sustainably by taking part in various training programs, seminars, and workshops individually and or in groups. Various programs of teacher professional development are held by the government, but the teachers are reluctant to join. Institutional partnerships among universities in Indonesia try to investigate how senior and vocational high school teacher's professionalism is developed from the aspects of the pedagogical competency, self-development, scientific publications, and innovative works.

Teachers are an integral part of the education system in schools so that they must be able to bring a conducive learning atmosphere for students to develop their potential in facing the changing demands of industry 4.0. A study by Guskey (2003) shows that teacher professionalism has a positive impact on teacher independence and student achievement. Independent professional development is considered essential for teachers as universities, in general, are not capable of providing a variety of services for their alumni. Teachers need years of experience to be able to conduct an effective teaching-learning process. Moreover, they need to continuously learn about the challenges and demands of the fourth industrial era revolution (Mizell, 2010).

Specifically, the Regulation of the Minister of the Administrative and Bureaucratic Reform (Permen PAN 2009 No. 16) designed a continuous professional development program 
integrated with the teacher career development program which includes: (1) self-development, (2) scientific publications, and (3) innovative works. Thus, every effort to develop a teacher career position is always related to the improvement of four teacher competencies, namely pedagogical, professional, personality, and social. Professional development integrated with the development of teacher career positions has positive impacts on teacher professionalism as they need to keep on developing their professionalism continuously to deal with as well as to adapt and adjust to internal and external changes and the uncertainties in the fourth industrial era. This is in line with Trorey (2002) who states that professional development goes along with self-development. This development involves the process of developing their own abilities that will be used in various internal and external situations in schools. In addition, Day (2002) shows the positive long-term impacts of orientation and benefits of professional development on career and functional roles.

This means that senior high school teachers should carry out self-development in order to adapt to changes. This research tries to depict the effort done by senior and vocational high school teachers to independently develop their professionalism with the support from schools. The schools are located in two provinces, the Special Region of Yogyakarta and West Kalimantan.

\section{METHODS}

This study employed the survey method with a quantitative descriptive approach. The participants of this study were 113 teachers of senior and vocational high schools located in the Special Region of Yogyakarta and West Kalimantan. The sample was collected using multistage sampling. In the first phase, using the cluster sampling, regencies and cities in Special Region of Yogyakarta and West Kalimantan were selected. Meanwhile, the second phase of the sampling process employed was the combination of another sampling technique as at least two techniques (Barreiro \& Justo, 2001). The sample was selected using the multistage technique presented in Table 1 .

Table 1. Research Sample

\begin{tabular}{llllllll}
\hline \multirow{2}{*}{ Educational Background } & \multicolumn{3}{l}{ Special Region of Yogyakarta } & \multicolumn{2}{c}{ West Kalimantan } \\
\cline { 2 - 8 } & Sleman & $\begin{array}{l}\text { Gunung } \\
\text { Kidul }\end{array}$ & Bantul & $\begin{array}{l}\text { Kulon } \\
\text { Progo }\end{array}$ & Yogyakarta & Pontianak & Bengkayang \\
\hline Bachelor's/Diploma Degree & 9 & 6 & 7 & 5 & 9 & 25 & 24 \\
Master's Degree & 2 & 4 & 1 & 4 & 4 & 7 & 6 \\
Doctoral Degree & 0 & 0 & 0 & 0 & 0 & 0 & 0 \\
\hline Total & 11 & 10 & 8 & 9 & 13 & 32 & 30 \\
\hline Percentage (\%) & 9.7 & 8.8 & 7.1 & 8.0 & 11.5 & 28.3 & 26.5 \\
\hline
\end{tabular}

The developed instruments referred to aspects of pedagogical competency, selfdevelopment, scientific publications, and innovative works. These four aspects were put into 11 indicators which were then developed into 34 statements in a questionnaire. The questionnaire was reviewed by 10 education experts in a focus group discussion. The blueprint of the questionnaire is presented in Table 2. The instruments for collecting the primary data were open-ended and closed-ended questionnaires. The data analysis technique employed was descriptive statistics that processed the data into percentages.
Table 2. The Blueprint of Teacher Professionalism Instrument

\begin{tabular}{|c|c|}
\hline Aspect & Indicator \\
\hline $\begin{array}{l}\text { Pedagogical } \\
\text { competency }\end{array}$ & $\begin{array}{l}\text { Teaching preparation } \\
\text { Teaching practice } \\
\text { Information technology utilization }\end{array}$ \\
\hline $\begin{array}{l}\text { Self- } \\
\text { development }\end{array}$ & $\begin{array}{l}\text { Educational development } \\
\text { Training program } \\
\text { Teacher role in workshop and semina }\end{array}$ \\
\hline $\begin{array}{l}\text { Scientific } \\
\text { publication }\end{array}$ & $\begin{array}{l}\text { Research } \\
\text { Scientific publications } \\
\text { Learning materials }\end{array}$ \\
\hline $\begin{array}{l}\text { Innovative } \\
\text { work }\end{array}$ & $\begin{array}{l}\text { The invention of appropriate } \\
\text { technology } \\
\text { Award for technology-based work }\end{array}$ \\
\hline
\end{tabular}




\section{FINDINGS AND DISCUSSION Findings}

The result of research on senior and vocational high school teacher professionalism is grouped into four aspects, namely pedagogical competency, self-development, scientific publications, and innovative works.

\section{Pedagogical Competency}

The teachers concern five aspects when preparing a lesson (see Table 3). The variety of sources used by teachers to prepare lessons is presented in Figures 1 and 2. The teachers' opinions in digital sources utilization during learning are presented in Figures 3 and 4.

From a series of teacher activities in preparing learning, it is shown that the teachers do not possess sufficient competency in planning assessment. This is in line with the result of research conducted by Khodijah (2013). The research is on post-certification teacher performance viewed as a whole and from the average learning assessment indicators. It is shown that teacher performance is below the minimum standard of performance.

Table 3. Aspect being Considered in Teaching Preparation

\begin{tabular}{llcc}
\hline \multirow{2}{*}{ No. } & \multirow{2}{*}{ Aspect } & \multicolumn{2}{c}{ Total (\%) } \\
\cline { 3 - 4 } & & Incorrect & Correct \\
\hline 1. & Developing competency achievement indicators & 24.8 & 75.2 \\
2. & Constructing learning goals & 31.0 & 69.0 \\
3. & Determining the topic of learning materials & 40.7 & 59.3 \\
4. & Planning the main learning activities & 34.5 & 66.5 \\
5. & Developing blueprint of assessment instrument & 91.2 & 8.8 \\
\hline
\end{tabular}

Various sources from the Internet
Compilation of various sources
Student worksheet
Published books
Previous learning materials

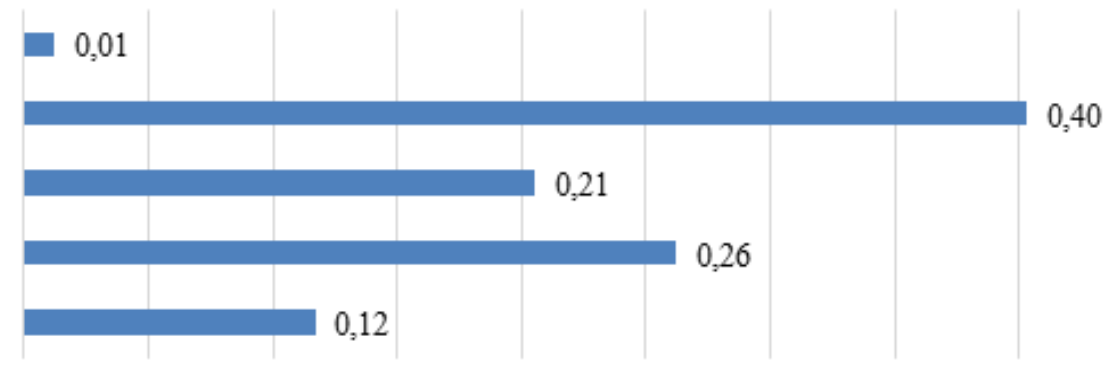

Figure 1. Teacher Professionalism in Utilizing Various Learning Sources

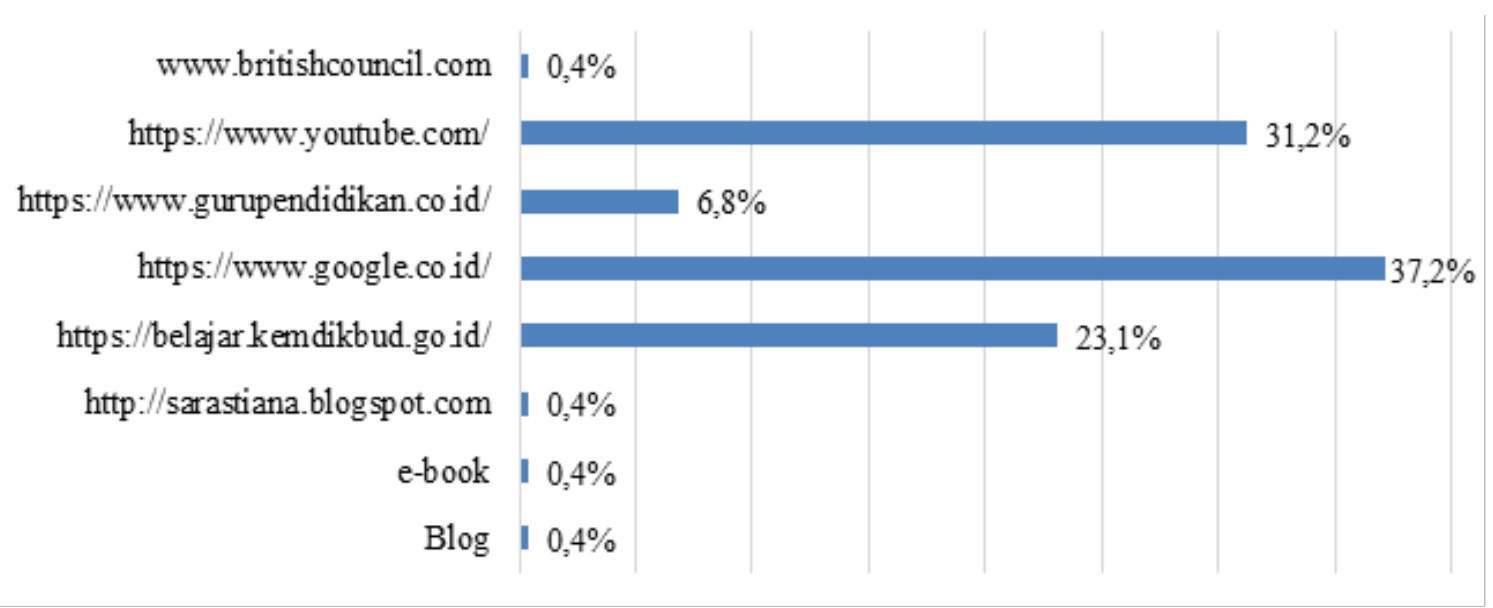

Figure 2. Teacher Professionalism in Utilizing Various Online Learning Source 


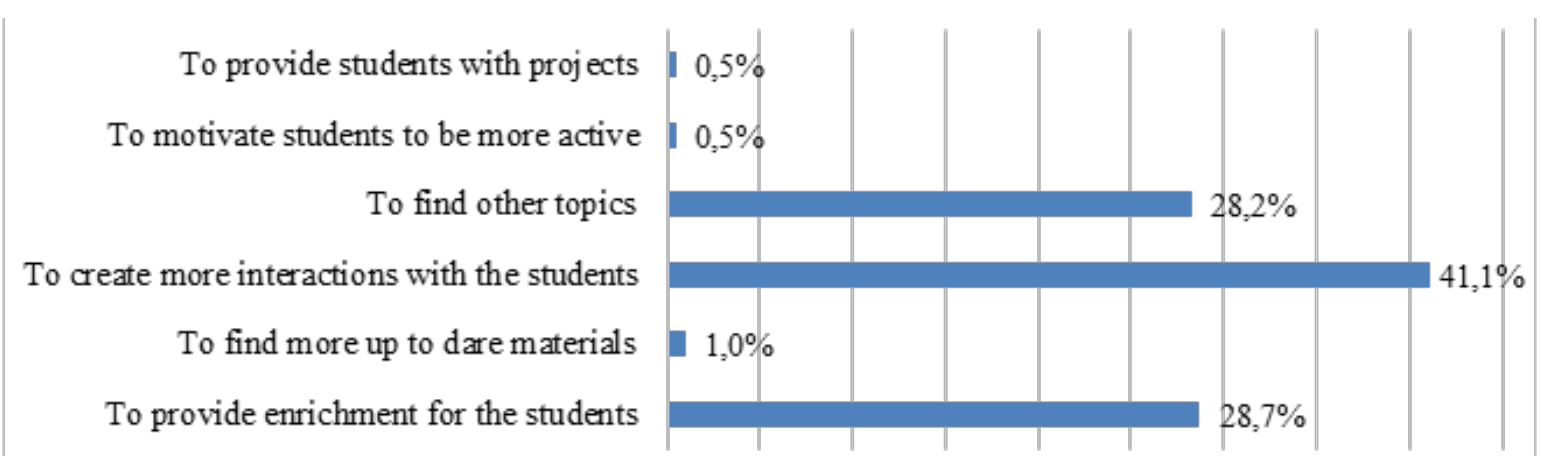

Figure 3. The Teacher's Rationality in Utilizing Various Information Technology and Computer-Based Learning Resources

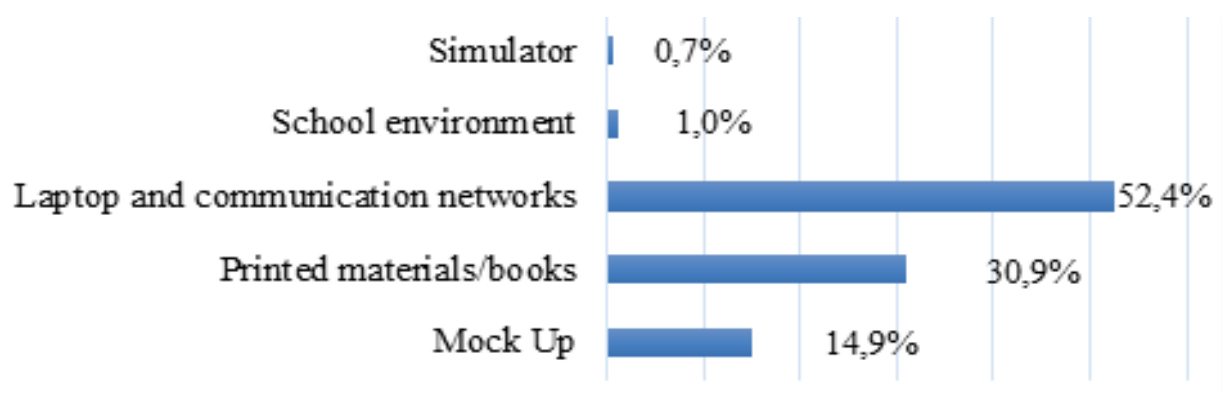

Figure 4. Teacher Professionalism in Utilizing Information, Technology, and Computer

\section{Self-Development}

Teachers develop their professionalism through many programs. Table 4 show the four types of training commonly attended by teachers.

\section{Scientific Publications}

In the last five years, the number of education and teaching learning-related scientific or popular works published by teachers is presented in Figure 5.

\section{Innovative Works}

The teacher's effort to create innovative works in the last five years is shown in Figure 6.

Table 4. Four Types of Training Commonly for Teachers

\begin{tabular}{lcccc}
\hline \multirow{2}{*}{ Frequency } & \multicolumn{4}{c}{ Training (\%) } \\
\cline { 2 - 5 } & $\begin{array}{c}\text { Classroom } \\
\text { Action Research }\end{array}$ & $\begin{array}{c}\text { Scientific } \\
\text { Publications }\end{array}$ & Curriculum & Study Program \\
\hline > Four times & 5.6 & 7.1 & 3.2 & 13.5 \\
Three - four times & 12.7 & 17.9 & 33.0 & 20.3 \\
Once - twice times & 53.5 & 39.3 & 37.2 & 51.4 \\
Never & 28.2 & 35.7 & 26.6 & 14.8 \\
\hline
\end{tabular}

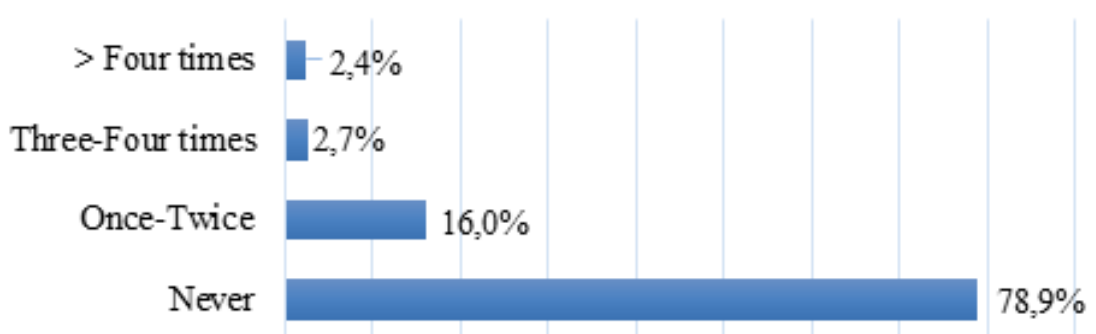

Figure 5. The Number of Journal Articles Published by the Teachers 


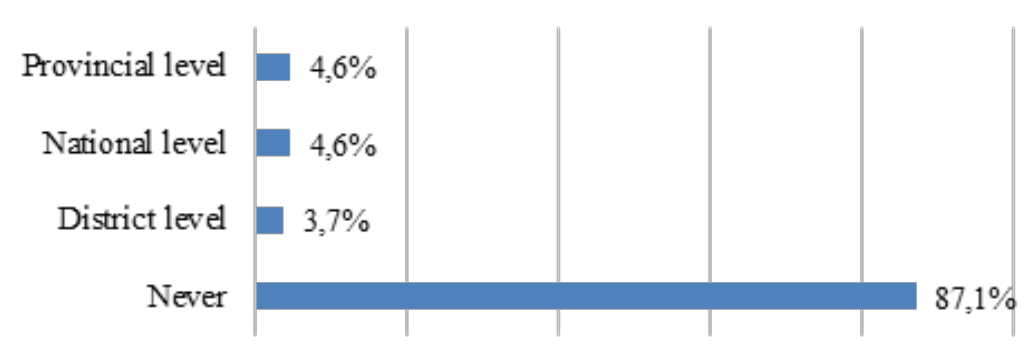

Figure 6. The Number of Awards for Teacher Innovative Works

\section{Discussion}

In terms of post-certification, when viewed from educational qualification, as many as $29 \%$ of teachers in the Special Region of Yogyakarta and West Kalimantan have done self-development by participating in training programs for teaching as a profession/PPG (4.2\%) and getting a master's degree (24.8\%). Meanwhile, $71 \%$ of the teachers have bachelor's degree.

\section{Teacher Professionalism in Teaching}

In carrying out professional duties as educators, teachers have understood their duties and obligations with the following indicators: a) more than half of the teachers $(54.2 \%)$ in Yogyakarta and West Kalimantan understand the 2013 curriculum from primary sources; b) $60 \%$ of the teachers develop lesson plans at the beginning of each semester; and c) $44 \%$ of the teachers prepare lesson plans independently.

In implementing the 2013 curriculum, teachers understand that they need to get various learning sources. More than half of the teacher respondents in Yogyakarta and West Kalimantan get the knowledge of the 2013 Curriculum from primary sources. As many as $37.2 \%$ of the teachers understand the content of the 2013 Curriculum after participating in the training held by the Education and Culture Provincial/ City/Regency Offices. As many as $17.0 \%$ of the teachers attend workshops and training held by the Ministry of Education and Culture in Jakarta. Then, $26 \%$ of the teachers understand the 2013 curriculum from a secondary source, namely a) discussion among peer teachers participating in the 2013 Curriculum training (26.0\%), and b) independent learning from various sources (18.4\%).

In carrying out professional duties as educators, teachers already have understood their duties and obligations to be prepared before teaching including developing lesson plans. They know the right moment to develop a lesson plan. As many as $60 \%$ of the teachers develop lesson plan at the beginning of a semester, $19 \%$ of them develop lesson plans during workshops held by their schools, $17 \%$ of them develop lesson plans right before teaching, and only $4 \%$ of them are not able to develop lesson plans on time. In teaching for a semester, $44 \%$ of the teachers develop the lesson plans individually, $31 \%$ of the teachers develop the lesson plans together in a teacher forum, and $14 \%$ of the teachers work together in a workshop held by their schools. Based on the teachers' responses, it can be concluded that teacher pedagogical competency depends mainly on the teacher's activeness in working individually. Moreover, teacher forums positively contribute to teacher pedagogical competence improvement.

Figures 2 and 3 show in detail how teachers manage the teaching-learning process by utilizing various learning sources. In this Industry 4.0, learning sources used should be in accordance with the student characteristics. One of their characteristics in learning is the use of digital learning sources. This is somehow in line with Gore (2013); Voogt \& Roblin's (2012) concept that information technology, computer, effective communication, digital literation can improve student potential.

Teachers commonly use some strategies to get learning sources, namely a) compiling material from various printed sources $(40.3 \%)$, b) using books published by the Ministry of Education and Culture (26.2\%), c) using student worksheets compiled by the teachers $(20,1 \%)$, and d) using existing teaching materials (11.7\%). With the availability of adequate printed learning resources, teachers now get used to using them in teaching. Thus, the internet, information technology, computer-based learning format does not get much attention $(1.2 \%)$ as the 
teachers have limited internet bandwidth, no WiFi facilities, and limited internet quota to connect smartphones to the internet network. There are four websites that are predominantly used by teachers. They are a) https://www.google.co.id/ $(37.2 \%)$, b) https://www.youtube.com/ (31.2\%), c) https://belajar.kemdikbud.go.id/ (23.1\%), and https://www.gurupend Pendidikan.co.id/. Then, IT-based learning sources that are commonly used by the teachers are a) Microsoft office programs, for example, MS Word, MS Excel and MS PowerPoint (54.2\%), b) multimedia programs (18.7\%), and c) programs evaluation, such as cahoots and google form (12.8\%).

The data analysis shown in Figures 4 and 5 shows the teacher's answers for a question"why online learning resources provide a very interesting analysis?". Most of the teachers say that media based on information technology and computer can make students more active in the teaching-learning process $(41.1 \%)$. Then, ICT provides rich sources to the subject $(28.7 \%)$, and ICT is the only learning source as no books available for the learning materials (28.1\%). Other teachers argue that the learning materials provided on the internet are more up to date, thus motivating students to be active in class. Furthermore, it has many tasks and projects for students to complete. It is time for teachers in the fourth industrial era to consider integrating ICT in learning more frequently because the students that they are now teaching have different preferences from the students that taught 10 years ago. Integrating more ICT at this time will make teachers more creative in designing learning so that learning is more interesting (Hussin, 2018). Similarly, Prestridge, Tondeur, \& Ottenbreit-Leftwich (2019) argue that the use of ICT-based media lets teachers explore more ideas to teach and as a result, students will have chances to learn from various resources.

Teachers make use of ICT-based learning resources as learning media to motivate the students to actively participate in learning both in classrooms and outside the classrooms. In addition, the teachers want to update the subject matter, as well as expand the knowledge of the subject matter that is not available in the books. The advancement of information technology and the computer has become the basis for teachers to use technology in every lesson. Most of the respondents use their laptops and the internet to optimize learning processes $(52.4 \%)$. As many as $30.9 \%$ of the teachers use books only, and $14.9 \%$ of them use realia. However, there are few teachers who make use of realia, simulator, and teaching aids. It indicates that senior and vocational high school teachers prefer to use conventional learning strategies. Herold (2015) stated that the way teachers use learning technology to integrate conventional learning strategies becomes a promising starting point in professional development programs. However, most teachers should better understand how technology should be implemented into teaching and learning processes to transform into studentcentered learning and improve with the use of technology (Chen, 2008). In other hand, Ananiadou \& Claro (2009) finds that utilizing ICT-based media can improve the teaching and learning process.

In learning, teachers should be aware of how to utilize learning materials, such as student worksheets, modules, practicum sheets. Based on the result of this study, it is found that teachers choose learning materials based on a) basic competencies $(41 \%)$, b) student characteristics (33\%), and c) curriculum (21\%). Meanwhile, the main considerations for teachers in choosing learning sources and learning media are a) learning objectives $(42 \%)$, b) student characteristics (32\%), and c) curriculum implementation (14\%). The main consideration of the teachers in preparing test items are a) learning objectives (38\%), b) basic competencies $(36 \%)$, and c) subject matter $(25 \%)$. This illustrates that more than a third of the teachers have excellent pedagogical competency in understanding the principles of the assessment process and student learning outcomes. Barry (2010) states that effective teachers are those who understand student characteristics, learning styles, and potential as learners. Moreover, good teachers understand teaching material (content) well, so they pay more attention to the learning that is carried out. For future vocational teachers, the core competencies that are relevant to the hard skill aspect are pedagogical knowledge, content knowledge, and educational technology.

\section{Teacher Self-Development}

In this 4.0 industrial era, Yogyakarta and West Kalimantan provincial offices should encourage and provide more opportunities for 
teachers to develop themselves through training programs, programs for teaching as a profession, further education level (master's program). Teachers in Yogyakarta and West Kalimantan have participated in various pedagogical training, teaching material discussion, and classroom action research. In addition, they have contributed to scientific publications writing. This idea is in line with Ganser's (2002) that teacher professional development in 4.0 Industry involves two types of experiences, namely formal experiences (participating in training, workshops, etc.), and informal experiences (reading scientific publications/academic journal articles, etc.).

Of the various types of training attended by senior and vocational high school teachers in both provinces, it is shown that the number of teachers taking the initiative to pay for themselves is $21.5 \%$. Most of the teachers chose various training programs to improve pedagogical competency organized by a) the Ministry of Education and culture/provincial education office $(50.6 \%)$, b) Subject Teacher Forum $(23.3 \%)$, and c) professional institutions $(4.7 \%)$. The most common types of professional development training participated by teachers are on classroom action research, scientific publications, the 2013 curriculum, and teaching materials. The percentages presented in Figure 3 show the teacher participation in training programs. Basic training programs joined by most teachers are in the form of seminars and workshops. These types of training programs help teachers improve pedagogical competencies and knowledge of learning materials which are then delivered to students.

Most teachers participate in training related to subject development $(85.2 \%)$. Other training programs are training on curriculum $(73.4 \%)$, training on classroom action research $(71.8 \%)$, and training on scientific publications (63.4\%). Several training programs joined by the teachers are an effort to improve the quality of teaching-learning processes and student learning achievement. Continuous teacher professional development serves as the basis for the field of education in this 4.0 industrial era. Özden (2010) argues that the main goal of professional development is to always improve and develop the quality and qualifications of teachers to update knowledge, skills, and behavior so that they can teach better.

Classroom action research and scientific publications are two most common training programs for the teachers. These programs do not only develop their professionalism, but they also support the teacher functional career. To develop professionalism and career, as many as $82.2 \%$ of the teachers chose to actively participate in seminars and workshops, and $28.3 \%$ of them chose to become the speakers in seminars and workshops. The trend of research and professional development of teachers in the 4.0 industrial era includes inquiry methods, problem-solving, action research, thinking skills, and other learning strategies and methods (Aldahmash, Alshamrani, Alshaya, \& Alsarrani, 2019). Although most senior and vocational high school teachers have attended various training and seminars/workshops, they sometimes are not able to apply the knowledge. Coll \& Taylor argue that it is not effective if a teacher attends only one workshop because their basic need is knowledge of technology to be applied in effective teaching (Coll \& Taylor, 2011).

\section{Teacher Scientific Publications}

PP RI 2005 No. 19, article 28, paragraph 3 , enacts that social competency is teacher ability to communicate and interact effectively with students, fellow teachers, parents of students, and community. To develop professionalism, the teacher's ability to communicate is specifically focused on classroom action research, scientific publications, and learning module writing.

Besides, teachers trying to get a better functional position, for example from IIIb to IIIc, must have a credit score from scientific publications and/or innovative works (Permen PAN 2009 No. 16, article 17). The teachers' lack of competency in publishing ideas in scientific articles may become the obstacle to getting promoted.

Teachers are required to publish scientific/ popular articles in the field of education and/or learning in scientific journals. Although $74.3 \%$ of teachers have attended the training, even $25 \%$ of them have attended the training more than twice, $78.2 \%$ of the teachers have never published their writing. In the last five years, $21.7 \%$ of senior and vocational high school teachers rarely publish their research. Rahyasih, Hartini, \& Syarifah (2020) state that teachers' scientific 
publications still need to increase in number. It also needs more attention both individually and institutionally. More specifically, Hafiar, Damayanti, Subekti, \& Fatma (2015) emphasize that scientific publications training programs are efforts to provide technical guidance, especially to improve and develop teacher ability in writing.

In terms of professional experiences as educators, most of the teachers have developed learning materials in the form of modules and student worksheets $(80.9 \%)$. However, there are still teachers who never develop learning materials $(19.1 \%)$. Of the various formats of teaching materials developed by the teachers above, most writings being developed have never been published by a publisher with an ISBN (83.8\%), and only $16.2 \%$ of senior and vocational high school teachers have compiled published teaching materials with an ISBN. This is in line with Rahyasih et al. (2020) study result that $80 \%$ (high category) of teachers have compiled learning modules and textbooks with ISBN.

\section{Teacher Innovative Works}

In terms of professional development, as educators, senior and vocational high school teachers are expected to provide ideas and practices which are based on and are accepted as a new invention by other teachers or certain groups. Their works are to be applied in learning. The results of this study show that as many as $87 \%$ of the respondents have never made any contribution to improve the quality of learning. The data on innovative works show that works exhibited at the district level are 3.8\%, works exhibited at the provincial level are $4.7 \%$, and works exhibited at the national level are $4.7 \%$. Meanwhile, the percentage of innovative works receiving awards from the district office is $5.9 \%$, $5.0 \%$ at the provincial level, and $2.0 \%$ at the national level. The rest (87.1\%) never get any recognition.

As many as $78.2 \%$ of the teachers have never published their scientific work, and $87 \%$ of them have never produced any innovative works. These will result in a bottleneck of career for them. From the statistics, it is seen that $50.4 \%$ of senior high school teachers and $51.3 \%$ of vocational high school teachers in Yogyakarta do not get promoted to the IVa level. Similarly, in West Kalimantan, $48.2 \%$ of teachers teaching at senior high schools and $43.3 \%$ of teachers teaching at vocational high schools do not get promoted to the IVb level. The obstacles of being promoted are mainly caused by the lack of scientific publications and innovative works.

\section{CONCLUSION}

To conclude, this research found that (1) Senior and vocational high school teachers in the Special Region of Yogyakarta and West Kalimantan province have developed their professionalism by participating in various training programs. (2) As many as $73.68 \%$ of the teachers in both provinces have participated in training programs on classroom action research $(24.4 \%)$, scientific publications (21.8\%), curriculum development $(24.9 \%)$, and up to date learning materials (28.9\%). (3) Teachers in both provinces have a relatively small number of articles published in journals $(21.8 \%)$ although most of them $(80.9 \%)$ have developed modules and student worksheets.

\section{ACKNOWLEDGEMENT}

This research is supported by the Institute for Research and Community Service, Yogyakarta State University under UNY Rector's Decree No. 1.30 / UN34 / IV / 2019, as well as the Forum for Research and Community Service Institutions for the Association of Indonesian Education Institutions for Education Personnel.

\section{REFERENCES}

Aldahmash, A. H., Alshamrani, S. M., Alshaya, F. S., \& Alsarrani, N. A. (2019). Research trends in in-service science teacher professional development from 2012 to 2016. International Journal of Instruction, 12(2), 163-178. https://doi.org/10.29333/ iji.2019.12211a.

Ananiadou, K., \& Claro, M. (2009). 21stcentury skills and competencies for new millennium learners in OECD countries (OECD education working papers No. 41). https://doi.org/10.1787/218525261154.

Atay, D. (2006). Teachers' professional development: Partnership in research. The Electronic Journal for English as a Second Language, 10(2), 1-15. http:// www.tesl-ej.org/wordpress/. 
Barreiro, P. L., \& Justo, P. A. (2001). Population and Sample: Sampling Techniques. Spain: MaMaEuSch. http://www.mathematik. unikl.de/ $/$ mamaeusch.

Barry, R. A. (2010). Teaching effectiveness and why it matters. Portland, OR: Marylhurst University and the Chalkboard Project.

Chen, C.-H. (2008). Why do teachers not practice what they believe regarding technology integration? The Journal of Educational Research, 102(1), 65-75. https://doi. org/10.3200/JOER.102.1.65-75.

Coll, R. K., \& Taylor, N. (2011). An international perspective on science curriculum development and implementation. In B. J. Fraser, T. Kenneth, \& C. J. McRobbie (Eds.). Second international handbook of science education (vol. 1). New York, NY: Springer, pp. 771-782. https://doi. org/10.1007/978-1-4020-9041-7_51.

Craft, A. (1996). Continuing professional development: Practical guide for teachers and schools. New York, NY: Routledge.

Darling-Hammond, L. (2000). Teacher quality and student achievement: A review of state policy evidence. Educational Policy Analysis Archive, 8(1), 1-44. https://doi. org/10.14507/epaa.v8n1.2000.

Day, C. (2002). Revising the purposes of continuing professional development. In G. Trorey \& C. Cullingford. (Eds.). Professionaldevelopmentandinstitutional needs. London: Routledge, pp. 49-76. https://doi.org/10.4324/9781315245966.

Desimone, L. M., Smith, T. M., Ueno, K. (2006). Are teachers who need sustained, contentfocused professional development getting it? An administrator's dilemma. Educational Administration Quarterly, 42(2), 179-215. https://doi. org/10.1177/0013161X04273848.

Ganser, T. (2002). The new teacher mentors: Four trends that are changing the look of mentoring programs for new teachers. American School Board Journal, 189(12), 25-27.
Gore, V. G. (2013). 21st-century skills and prospective job challenges. The IUP Journal of Soft Skills, 7(4), 7-14. https:// ssrn.com/abstract=2472784.

Guskey, T. R. (2003). What makes professional development effective? Phi Delta Kappan, 84(10), 748-750. https://doi. org/10.1177/003172170308401007.

Hafiar, H., Damayanti, T., Subekti, P., \& Fatma, D. (2015). Peningkatan pendidikan dan pengembangan kompetensi guru SMA Negeri 1 Katapang melalui partisipasi dalam publikasi akademis di media massa. [Improving education and developing the competence of teachers of SMA Negeri 1 Katapang through participation in academic publications in the mass media]. Jurnal Aplikasi Ipteks untuk Masyarakat, 4(2), 88-92. https://doi.org/10.24198/ dharmakarya.v4i2.10032.

Herold, B. (2015). Why ED-TECH is not transforming teaching: Student-centered, technology-driven instruction remains elusive for most. Education Week, 34(35), 8-14. http://www.edweek.org/ew/ toc/2015/06/11/index.html.

Hussin, A. A. (2018). Education 4.0 made simple: Ideas for teaching. Australian International Academic Centre PTY.LTD, 6(3), 92-98. https://doi.org/10.7575/aiac. ijels.v.6n.3p.92.

Khodijah, N. (2013). Kinerja guru madrasah dan guru pendidikan agama islam pasca sertifikasi di Sumatera Selatan. Cakrawala Pendidikan, 32(1), 91-102. https://doi. org/10.21831/cp.v5i1.1263.

Law RI 2003 No. 20. Sistem pendidikan nasional. [National education system].

Mizell, H. (2010). Why professional development matters. Oxford: Learning Forward.

Özden, Y. (2010). Öğrenme ve ögretme. Ankara: Pegem.

Permen PAN 2009 No. 16. Jabatan fungsional guru. [Teacher functional position].

Permenristekdikti RI 2017 No. 55. Standar 
pendidikan guru. [Teacher education standards].

PP RI 2005 No. 19. Standar pendidikan nasional. [National education standards].

Prestridge, S., Tondeur, J., \& Ottenbreit-Leftwich, A. T. (2019) Insights from ICT-expert teachers about the design of educational practice: The learning opportunities of social media. Technology. Pedagogy, and Education, 28(2), 157-172. https://doi.or g/10.1080/1475939X.2019.1578685.

Rahyasih, Y., Hartini, N., \& Syarifah, L. S. (2020). Continuous professional development for teacher through scientific publications. In Proceedings of 3rd International Conference on
Research of Educational Administration and Management (ICREAM 2019). Atlantis Press, pp. 387-389. https://doi. org/10.2991/assehr.k.200130.206.

Trorey, G. (2002). Meeting the needs of the individual and the institution. . In G. Trorey, \& C. Cullingford. (Eds.). Professional development and institutional needs. London: Routledge, pp. 1-14. https://doi. org/10.4324/9781315245966.

Voogt, J., \& Roblin, N. P. (2012). A comparative analysis of international frameworks for 21st-century competences: Implications for national curriculum policies. Journal of Curriculum Studies, 44(3), 299-321. https://doi.org/10.1080/00220272.2012.6 68938. 